\title{
A Stored Products Pest (no official common name), Oryzaephilus acuminatus (Insecta: Coleoptera: Silvanidae) 1
}

M. C. Thomas and R. E. Woodruff ${ }^{2}$

\section{Introduction}

A commercial nursery in Fort Myers, Florida imported seeds of the neem tree (Azadirachta indica A. Juas) from India to be used for their purported insecticidal properties. Beetles were discovered in the storage area on 11 January 1983 and were sent to the Florida Department of Agriculture for identification. They were identified by the senior author as Oryzaephilus acuminatus Halstead, constituting the first United States record. Recommendations were immediately made to fumigate the area where the seed was stored in order to prevent establishment of the pest.

A previous shipment of 1,000 kilos of the seed was made a year earlier, but no beetles were noted then. The present shipment, consisting of 3,000 kilos, left India in September 1982, arriving in Los Angeles (San Pedro) on 12 December 1982. It was then shipped to Miami and stored for about three weeks before being shipped to Fort Myers. There it was stored in a room with part of the previous shipment. Thousands of beetles (all stages) were found in the storage area. This area was fumigated and the surrounding nursery and greenhouse areas were treated. All subsequent inspections were negative (after nine months).

\section{Distribution}

Halstead (1980) recorded it from India, Sri Lanka, and England (imported on coconut shells). The discovery of this species in Fort Myers represents the first record of its occurrence outside the Old World (Halstead, personal communication).

\section{Description}

O. acuminatus is similar to the other two stored products species of Oryzaephilus found in the U.S. Adults are dark brown to black with recumbent golden setae. Males range in length from 3.4-3.7 mm; females from 3.3-3.5 mm. Body elongate, parallel sided, ratio of length to width 4.3-4.4:1 in males, 3.9-4.1:1 in females. Pronotum in large males elongate, 1.5-1.7:1; lateral ridges and anterior pronotal angles strongly developed (all above ratios

1. This document is EENY-188 (originally published as DPI Entomology Circular 257), one of a series of Featured Creatures from the Entomology and Nematology Department, Florida Cooperative Extension Service, Institute of Food and Agricultural Sciences, University of Florida. Published: January 2001. This document is also available on Featured Creatures Website at http://creatures.ifas.ufl.edu. Please visit the EDIS Website at http://edis.ifas.ufl.edu.

2. M. C. Thomas and R. E. Woodruff, Florida Department of Agriculture and Consumer Services, Division of Plant Industry, Gainesville, Florida.

The Institute of Food and Agricultural Sciences (IFAS) is an Equal Employment Opportunity - Affirmative Action Employer authorized to provide research, educational information and other services only to individuals and institutions that function without regard to race, creed, color, religion, age, disability, sex, sexual orientation, marital status, national origin, political opinions or affiliations. For information on obtaining other extension publications, contact your county Cooperative Extension Service office. Florida Cooperative Extension Service / Institute of Food and Agricultural Sciences / University of Florida / Larry R. Arrington, Interim Dean 
are from Halstead, 1980). The immature stages have not been described, but larvae resemble those of the saw- toothed grain beetle [O. surinamensis $(\mathrm{L})$. illustrated by Peterson (1979: fig. C49-A).

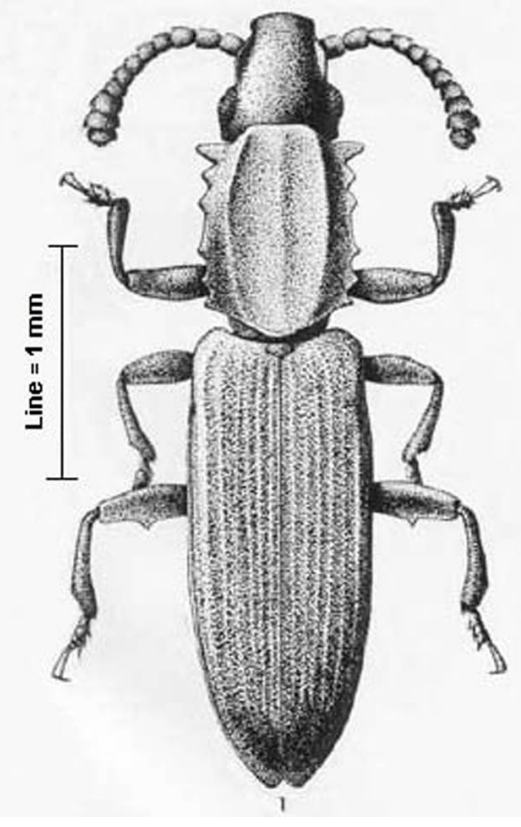

Figure 1. Adult male Oryzaephilus acuminatus Halstead, a stored products pest. Credits: Division of Plant Industry

In Cutler's (1971) key to the larvae of some economically important silvanids, $O$. acuminatus would key to $O$. mercator, the merchant grain beetle, sharing with that species the possession of 4 long, antero-lateral setae on abdominal tergites 2 to 7 .

\section{Biology}

In the original description, Halstead (1980) reported on crossing experiments among $O$. acuminatus, $O$. mercator, and $O$. surinamensis; $O$. acuminatus and $O$. mercator resulted in a few sterile hybrids; $O$. acuminatus and $O$. surinamensis were entirely unsuccessful. He noted in $O$. acuminatus that: "Its performance in cultures at constant temperatures suggests considerable pest potential." Some paratypes were designated from a culture of specimens collected in England in coconut shells imported from India.

After studying $O$. acuminatus at a variety of temperatures, humidities, and culture media, Jacob (1981) concluded that "... there are good reasons for concluding that $O$. acuminatus will not succeed as a storage pest as well as the other two species. $O$. acuminatus lays fewer eggs and this alone would probably lead to its failure in competition with them. Although it develops on cereals as quickly as $O$. mercator, its low rate of oviposition and considerable mortality of developing larvae and pupae ensure that its potential for increase is less."

\section{Identification Key}

Although $O$. acuminatus is superficially similar to both the saw-toothed grain beetle $(O$. surinamensis) and the merchant grain beetle $(O$. mercator) there are numerous structural differences distinguishing adults of the three species. Both $O$. mercator and $O$. acuminatus have relatively large eyes and short temples, while $O$. surinamensis has small eyes and long temples. Identification of $O$. acuminatus was confirmed by comparison with a paratype in the Florida State Collection of Arthropods. The following key, modified from Halstead (1980), should permit the identification of both sexes of these three species.

\section{Key to the United States Species of Oryzaephilus}

1. Temple at least one-half length of eye, not sharply angulate behind (Figure 6) ....O. surinamensis (L.), sawtoothed grain beetle

1'. Temple less than one-third length of eye, sharply angulate behind (Figure 5). . . . 2

2 . Anterior pronotal angle moderately developed in large males; body less elongate (3.6-4.1:1); pronotum of large males with lateral ridges not strongly elevated (Figures 2 and 4).... O. mercator (Fauvel), merchant grain beetle

$2 '$. Anterior pronotal angles strongly developed in large males; body more elongate (3.9-4.4:1); pronotum of large males with lateral ridges strongly produced (Figure 3 ) .... $O$. acuminatus Halstead, no common name

Male genitalia are also diagnostic for each species (see Halstead 1980). 


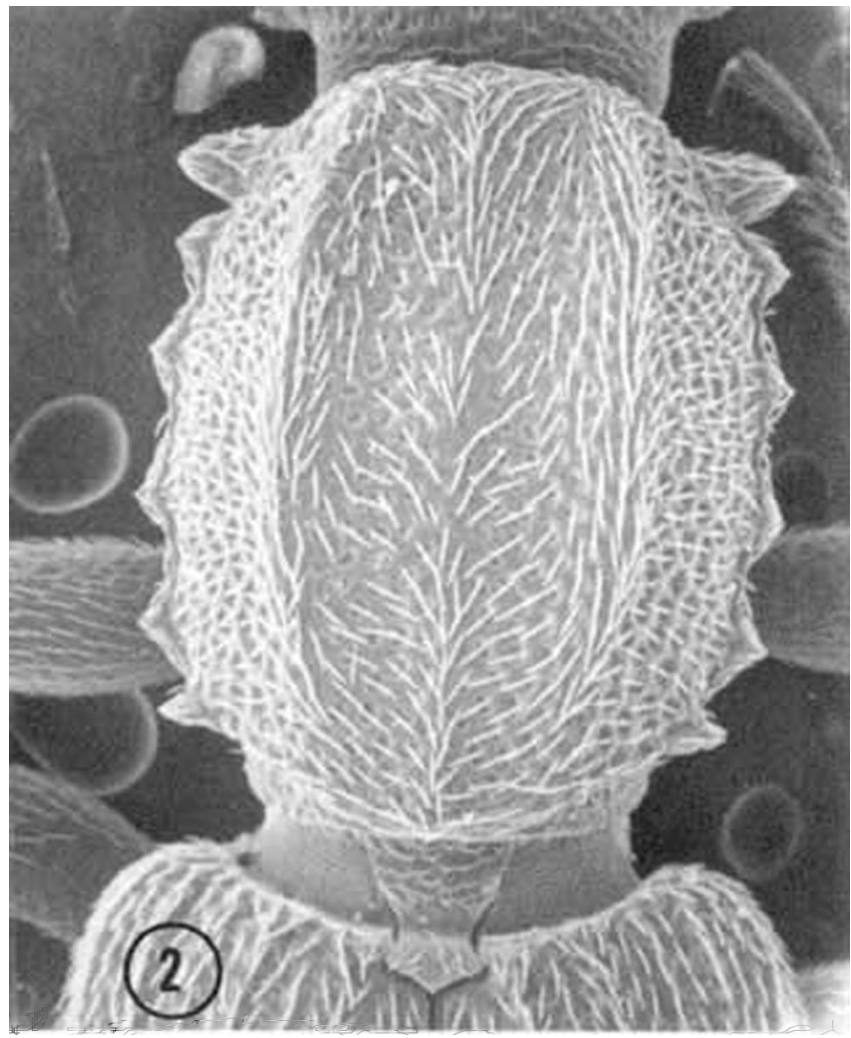

Figure 2. Oblique view of the pronotum of an adult male Oryzaephilus acuminatus Halstead, a stored products pest, showing the strongly developed anterior pronotal angles. Credits: Division of Plant Industry

Division of Plant Industry

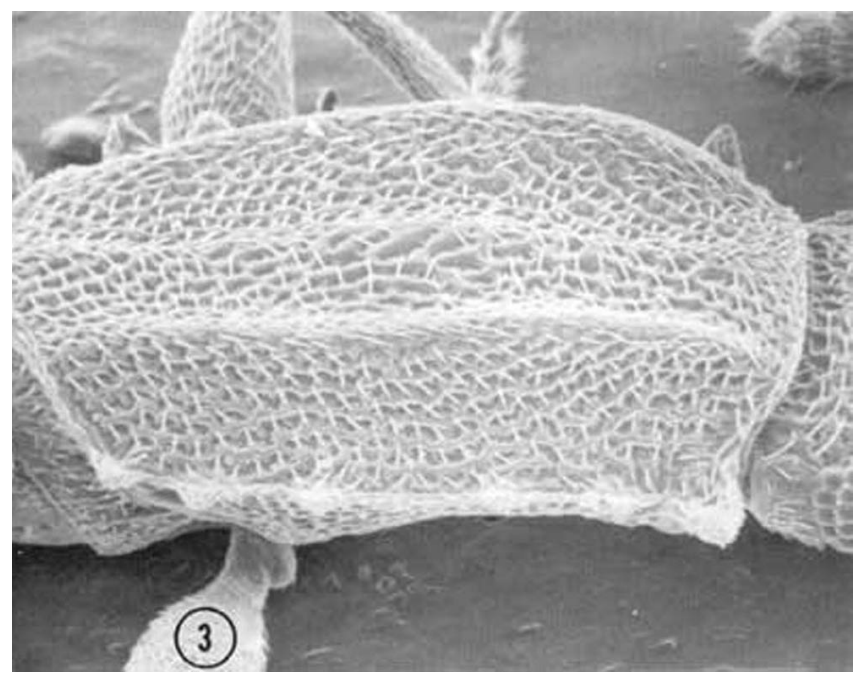

Figure 3. Dorsal view of the pronotum of an adult male Oryzaephilus mercator (Fauvel), the merchant grain beetle, showing lesser development of anterior pronotal angles, compared to $O$. acuminatus Halstead. Credits: Division of Plant Industry

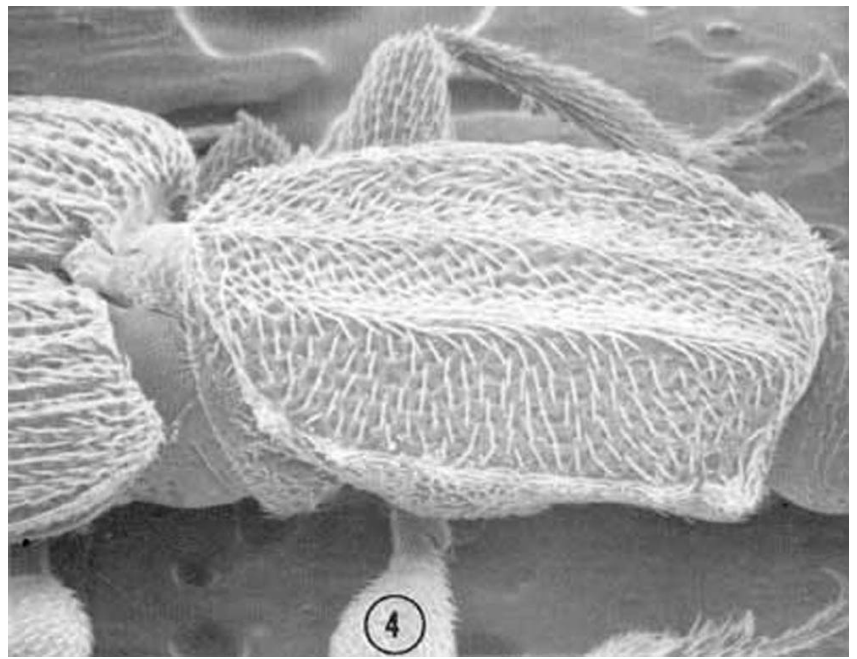

Figure 4. Oblique view of the pronotum of an adult male Oryzaephilus mercator (Fauvel), the merchant grain beetle, showing lesser development of anterior pronotal angles, compared to $O$. acuminatus Halstead. Credits: Division of Plant Industry

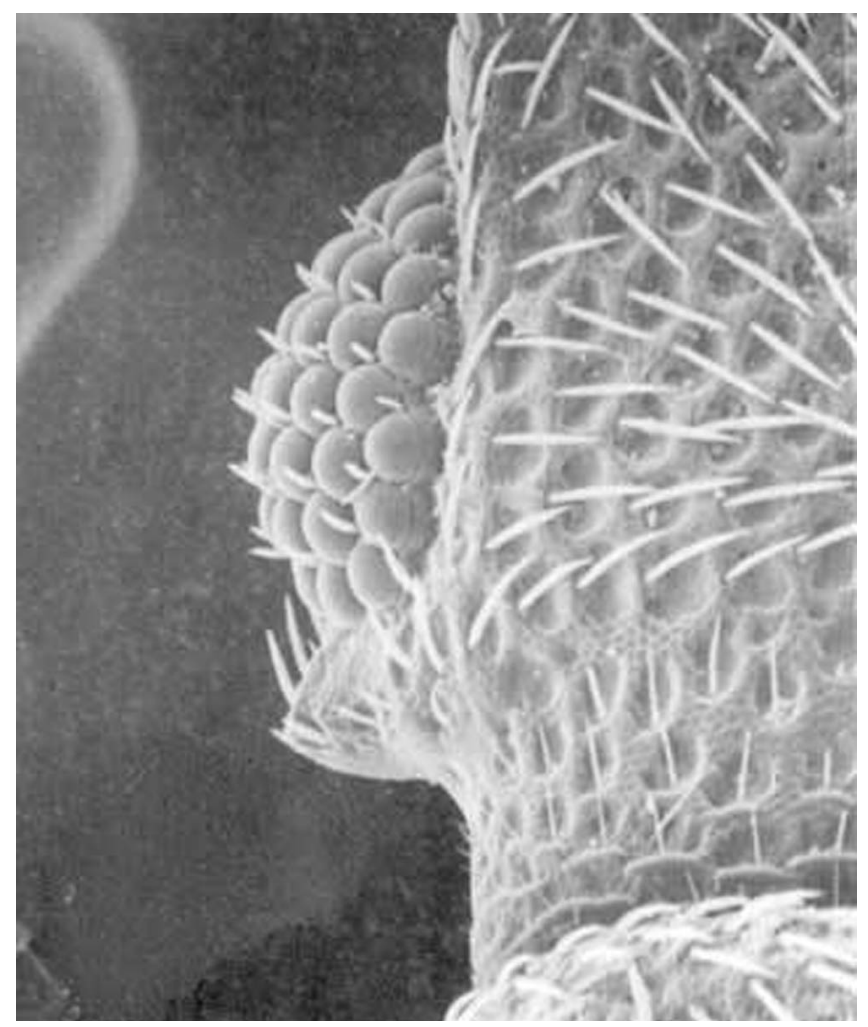

Figure 5. Dorsal view of the left eye and temple of an adult Oryzaephilus mercator (Fauvel). Credits: Division of Plant Industry

\section{Hosts}

The neem tree (Azadirachta indica A. Juas) is primarily Indian in distribution. At least one tree is growing at the USDA Plant Introduction Station in southern Miami. The beetle appears to thrive in dry 


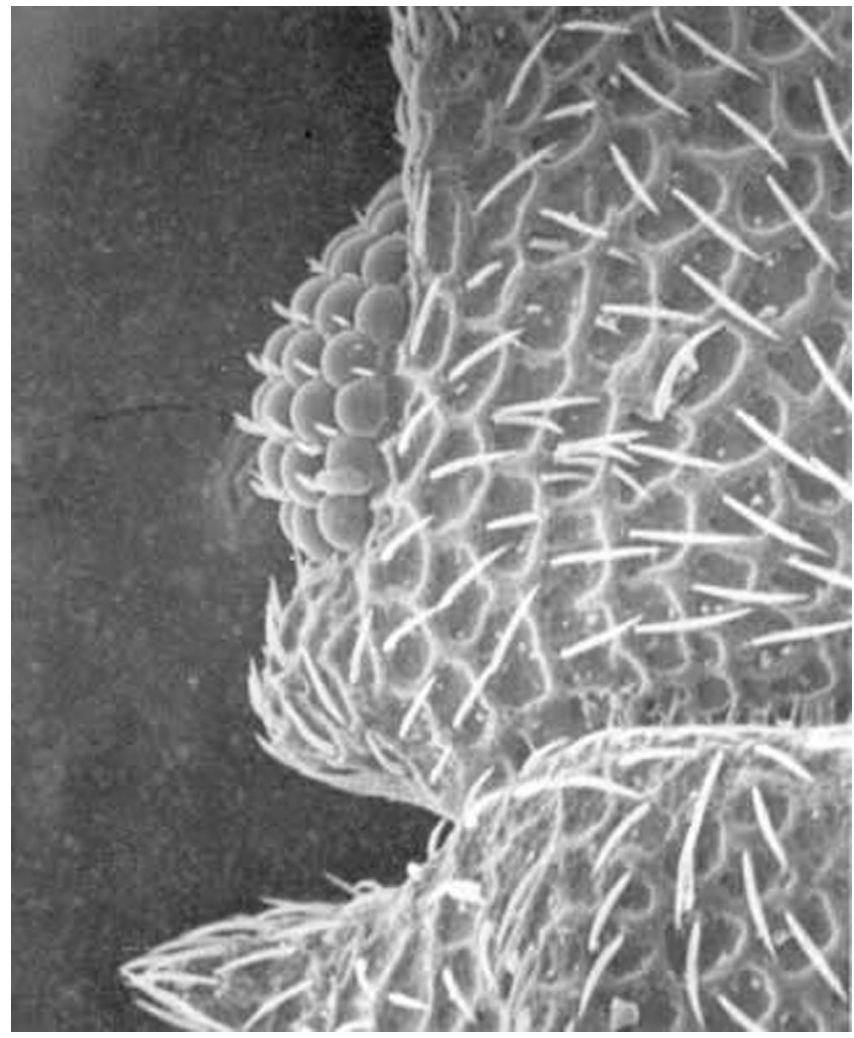

Figure 6. Dorsal view of the left eye and temple of an adult Oryzaephilus surinamensis (L.). Credits: Division of Plant Industry

stored materials; in this case seeds. Although these seeds are reported to have insecticidal properties, the chemical does not appear to be toxic to $O$. acuminatus.

Although some host preferences may exist, it is likely that any stored plant materials could provide sustenance. The British interceptions were in coconut shells, and it was cultured on groundnuts, on copra, and on a mixture of rolled oats, wheatfeed, and yeast in the laboratory. The saw-toothed grain beetle is found in flour, grains, seeds, and many kinds of stored products.

\section{Management}

For management information see the Insect Management Guide for Stored Grain Pests (http://edis.ifas.ufl.edu/IG103).

\section{Selected References}

Cutler JR. 1971. A key for distinguishing the larvae of Ahasverus advena (Waltl), Cathartus quadricollis (Guer.), Oryzaephilus surinamensis (L.) and Oryzaephilus mercator (Fauv.) (Coleoptera; Silvanidae). Journal of Stored Product Research 7: 125-127.

Halstead DGH. 1980. A revision of the genus Oryzaephilus Ganglbauer, including descriptions of related genera. (Coleoptera: Silvanidae). Zoological Journal of the Linnean Society 69: 271-374.

Jacob TA. 1981. Observations of the biology of Oryzaephilus acuminatus Halstead with comparative notes on the common species of Oryzaephilus (Coleoptera: Silvanidae). Journal of Stored Product Research 17: 17-23.

Koehler PG, Short DE, Fasulo TR. (1998). Pests In and Around the Home (http://pests.ifas.ufl.edu/software/det_pests.htm). UF/IFAS, SW-126.

Peterson A. 1979. Larvae of Insects: An Introduction to the Nearctic species. Part II. Coleoptera, Diptera, Neuroptera, Siphonaptera, Mecoptera, Trichoptera. Columbus. (Published by the author). $416 \mathrm{p}$. 